\title{
EFFECT OF ELECTRIC CURRENT ON THE PRODUCTION OF NiTi INTERMETALLICS VIA ELECTRIC-CURRENT-ACTIVATED SINTERING
}

\author{
VPLIV ELEKTRIČNEGA TOKA PRI IZDELAVI INTERMETALNE \\ ZLITINE NiTi S SINTRANJEM, AKTIVIRANIM Z ELEKTRIČNIM \\ TOKOM
}

\author{
Tuba Yener ${ }^{1}$, Shafaqat Siddique ${ }^{2}$, Frank Walther ${ }^{2}$, Sakin Zeytin ${ }^{1}$ \\ ${ }^{1}$ Sakarya University, Engineering Faculty, Department of Metallurgy and Materials Engineering, Esentepe Campus, 54187 Adapazari, Sakarya, \\ Turkey \\ ${ }^{2}$ TU Dortmund University, Faculty of Mechanical Engineering, Department of Materials Test Engineering (WPT), Baroper Str. 303, \\ 44227 Dortmund, Germany \\ tcerezci@sakarya.edu.tr
}

Prejem rokopisa - received: 2014-08-01; sprejem za objavo - accepted for publication: 2014-10-09

doi:10.17222/mit.2014.161

\begin{abstract}
This study focuses on investigating the fabrication of in-situ intermetallic NiTi composites from a powder mixture containing the mass fractions $50 \%$ nickel powder and $50 \%$ titanium powder. The elemental powders were mixed in the stoichiometric ratio corresponding to the NiTi intermetallic molar proportion of $1: 1$, ball-milled and uniaxially compressed under a pressure of $170 \mathrm{MPa}$. Sintering was then carried out for $15 \mathrm{~min}$ in a steel mold using the electric-current-activated sintering method. Electric-current values of $1000 \mathrm{~A}, 1300 \mathrm{~A}$ and $2000 \mathrm{~A}$ were used for the sintering while keeping the voltage in the range of 0.9 $\mathrm{V}$ to $1.2 \mathrm{~V}$. The phases in the samples were analyzed with XRD and their Vickers hardness was measured as $(701 \pm 166) \mathrm{HV}_{0.05}$. Energy dispersive X-ray spectroscopy carried out with a scanning electron microscope (SEM-EDS) showed that the microstructures of the samples consist of different phases such as $\mathrm{Ti}_{1}, \mathrm{Ni}_{2} \mathrm{Ti}_{3}, \mathrm{NiTi}_{2}, \mathrm{Ni}_{3} \mathrm{Ti}$ and $\mathrm{TiO}_{2}$ as a function of electric current. The XRD analysis also supported the SEM-EDS results. The nano-indentation technique was used to determine the elastic modulus of different phases.
\end{abstract}

Keywords: NiTi intermetallics, electric-current-activated sintering (ECAS), nano-indentation

Ta študija je usmerjena v preiskavo in situ izdelave intermetalnega NiTi-kompozita iz mešanice prahov z masnima deležema 50 $\%$ niklja v prahu in $50 \%$ titana v prahu. Obe vrsti prahu sta bili zmešani v stehiometričnem razmerju, ki ustreza molskemu razmerju NiTi $1: 1$, zmleti v kroglastem mlinu in enoosno stisnjeni pri tlaku 170 MPa. Petnajstminutno sintranje je bilo izvršeno v jeklenem kalupu s sintranjem, aktiviranim z električnim tokom. Pri sintranju so bili uporabljeni električni tokovi $1000 \mathrm{~A}, 1300 \mathrm{~A}$ in $2000 \mathrm{~A}$, medtem ko je bila napetost v območju med $0,9 \mathrm{~V}$ in $1,2 \mathrm{~V}$. Faze v vzorcih so bile določene z rentgenom (XRD) in izmerjena je bila trdota po Vickersu $(701 \pm 166) \mathrm{HV}_{0,05}$. Energijska disperzijska rentgenska spektroskopija (EDS), izvršena na vrstičnem elektronskem mikroskopu (SEM-EDS), je pokazala, da je mikrostruktura vzorcev sestavljena iz različnih faz, kot so $\mathrm{Ti}_{1} \mathrm{Ni}_{2} \mathrm{Ti}_{3}, \mathrm{NiTi}_{2}, \mathrm{Ni}_{3} \mathrm{Ti}$ in $\mathrm{TiO}_{2}$, odvisno od električnega toka. XRD-analiza je podprla rezultate, dobljene s SEM-EDS. Elastični modul različnih faz je bil določen z nanovtiski.

Ključne besede: intermetalna zlitina NiTi, sintranje, aktivirano z električnim tokom (ECAS), nanovtiski

\section{INTRODUCTION}

To meet the increasing demand of the aerospace and automobile industries for lightweight structural materials suitable for high-temperature applications, researchers focus on lightweight and high-strength intermetallics. ${ }^{1}$ Intermetallic compounds are promising materials for structural and non-structural high-temperature applications (heat resistance, corrosion resistance, electronic devices, magnets, super conductors)., ${ }^{2,3}$ Especially NiTi alloys are some of the most technologically important shape-memory alloys $\mathrm{s}^{4,5}$ which find extensive applications in the mechanical, medical, electronic, chemical and aerospace industries due to their excellent shape-memory effect, high erosion resistance, high damping capacity and biocompatibility. These properties make them suitable candidates for various engineering applications. ${ }^{2-7}$
Nickel titanium is a near-equiatomic intermetallic exhibiting distinctive and desirable thermo-mechanical properties, namely, the thermal shape-memory effect and super elasticity. ${ }^{8}$ Up to now, a number of processes including self-propagating high-temperature synthesis (SHS), thermal explosion, laser-melting deposition, casting and mechanical alloying techniques ${ }^{2,5,9,10}$ have been used for manufacturing intermetallics. In the electriccurrent-activated/assisted sintering (ECAS) technique, a cold-formed compact obtained with uniaxial compression is inserted into a container heated by the passing electrical current. A sintering pressure of $50 \mathrm{MPa}$ is applied and maintained throughout the sintering. ${ }^{11}$ The present study aimed to determine the effect of the current on the production of a NiTi intermetallic from the $\mathrm{Ni}$ and Ti elemental powders. 


\section{EXPERIMENTAL PROCEDURE}

\subsection{Materials and methods}

Powder materials from titanium $(99.5 \%$ purity, 35-44 $\mu \mathrm{m})$ and nickel (99.8 \% purity, 3-7 $\mu \mathrm{m})$ were used as the starting materials to manufacture a NiTi intermetallic compound. The Ni and Ti powders were mixed in the stoichiometric ratio corresponding to the $\mathrm{Ni}-\mathrm{Ti}$ phase diagram (Figure 1), in a molar proportion of $1: 1$.

The powder mixture was cold-pressed before the sintering to form a cylindrical compact in a metallic die under a uniaxial pressure of $170 \mathrm{MPa}$. Dimensions of a compact were $15 \mathrm{~mm}$ in diameter and $5 \mathrm{~mm}$ in thickness. The production of the NiTi intermetallic compounds was performed with the electric-current-activated sintering technique in an open atmosphere at 1000-2000 A for 15 min as shown in Figure 2. The process parameters are listed in Table 1.

Table 1: Process parameters for the samples Tabela 1: Procesni parametri pri vzorcih

\begin{tabular}{|c|c|c|c|}
\hline Sample code & $x / \%$ & Current (A) & Voltage (V) \\
\hline NT1 & $50 \mathrm{Ti}-50 \mathrm{Ni}$ & 1.000 & $0.9-1.2$ \\
\hline NT2 & $50 \mathrm{Ti}-50 \mathrm{Ni}$ & 1.300 & $0.9-1.2$ \\
\hline NT3 & $50 \mathrm{Ti}-50 \mathrm{Ni}$ & 2.000 & $0.9-1.2$ \\
\hline
\end{tabular}

After the sintering, the specimens were unloaded and air-cooled to room temperature. After metallographic preparations, the resulting microstructures and phase constitutions were characterized.

\subsection{Characterization}

The morphologies of the samples were examined with scanning electron microscopy (SEM-EDS) in terms of the resulting phases. An X-ray diffraction (XRD) analysis was carried out using $\mathrm{Cu}-K_{\alpha}$ radiation with a wavelength of $0.15418 \mathrm{~nm}$ over a $2 \theta$ range of $10-80^{\circ}$. The micro-hardness of the investigated samples was

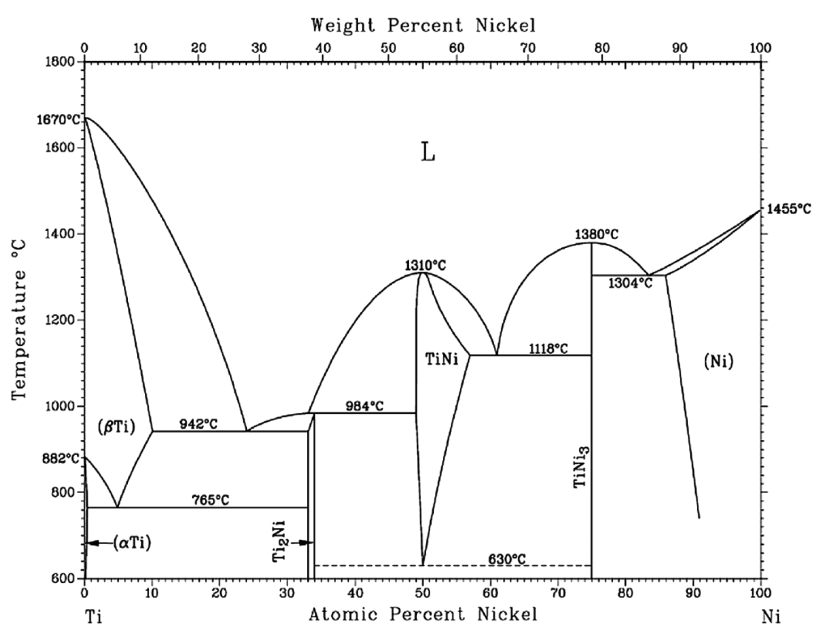

Figure 1: Ni-Ti phase diagram ${ }^{3}$ Slika 1: Fazni diagram Ni-Ti ${ }^{3}$

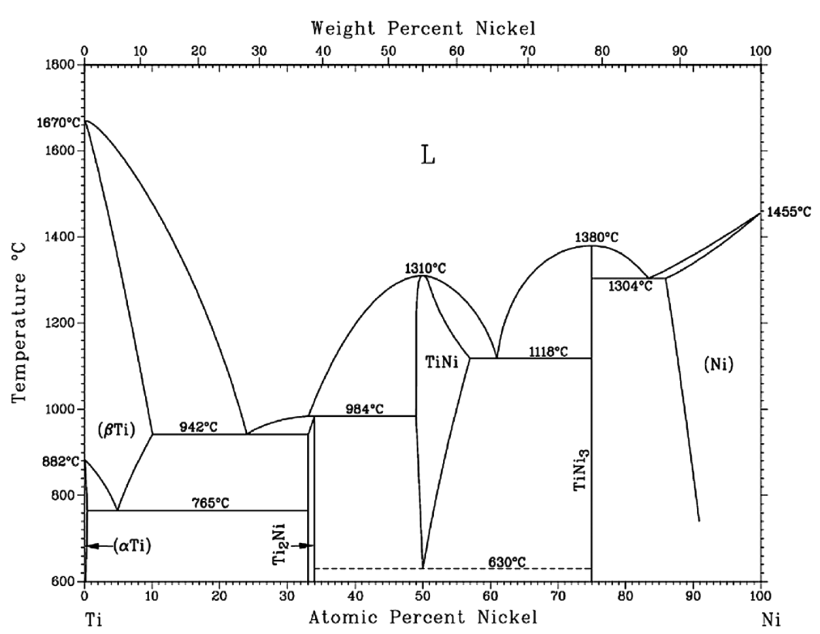

Figure 2: Schematic of electric-current-assisted sintering (ECAS) process

Slika 2: Shematski prikaz sintranja z električnim tokom (ECAS)

measured employing the Vickers-indentation technique with a load of $50 \mathrm{~g}$ using a Struers Duramin hardness instrument. For determining the elastic modulus of the samples, nano-indentation device DUH-211S by Shimadzu was used at a load of $98 \mathrm{mN}$ and a dwell time of $10 \mathrm{~s}$. The ImageJ programme was also used to determine the porosity of fractions of the samples.

\section{RESULTS AND DISCUSSION}

\subsection{SEM-EDS analysis}

The morphologies of the as-received $\mathrm{Ni}$ and $\mathrm{Ti}$ powders are shown in Figure 3. The metallic Ni-powder
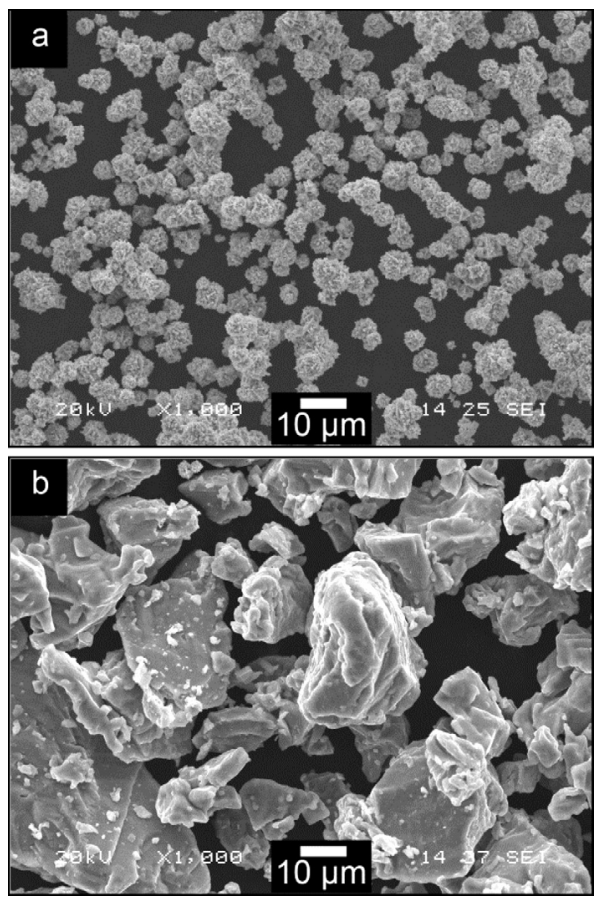

Figure 3: SEM micrographs of: a) Ni powder, b) Ti powder Slika 3: SEM-posnetka prahov: a) $\mathrm{Ni}$, b) $\mathrm{Ti}$ 


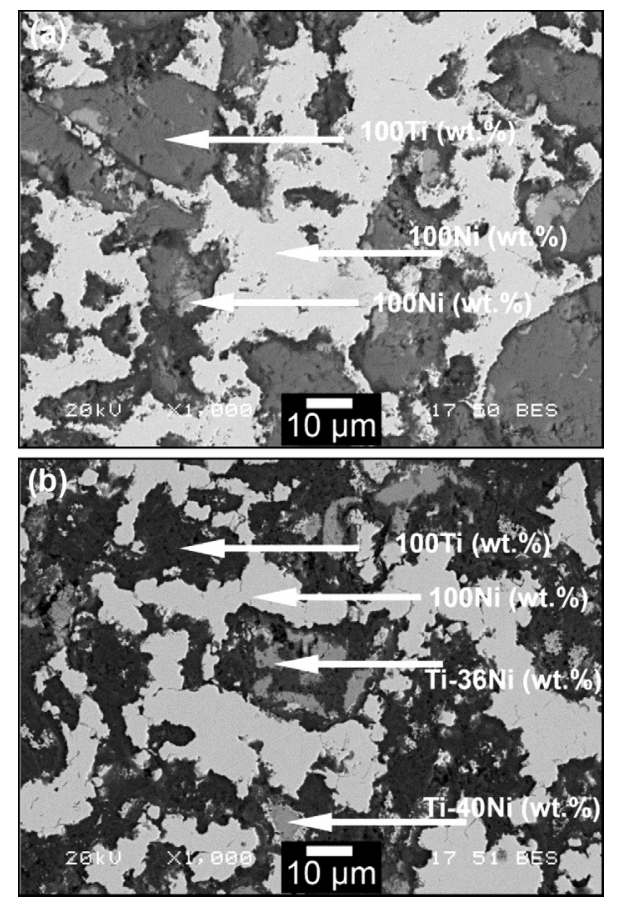

Figure 4: SEM-EDS analyses of: a) NT1, b) NT2 composites Slika 4: SEM-EDS-analizi kompozitov: a) NT1, b) NT2

particles were generally spherical with a diameter of 4-7 $\mu \mathrm{m}$. The Ti-powder particles had sharp corners and were less than $40 \mu \mathrm{m}$ in size.

SEM-EDS analyses of the NT1 and NT2 intermetallic compounds are shown in Figure 4. The microstructure in Figure 4a shows that a low current intensity results in separately formed $\mathrm{Ni}$ and $\mathrm{Ti}$ areas. When increasing the values of the current for NT2 (Figure 4b), new phases like $\mathrm{NiTi}_{2}$ (Figure 1) start to form, but these microstructures are still far from the stoichiometric composition of the main NiTi phase.

When increasing the current to 2000 A for the NT3 sample (Figure 5), the main phases in the microstructure such as $\mathrm{NiTi}, \mathrm{NiTi}_{2}, \mathrm{Ni}_{3} \mathrm{Ti}$ are evident. Besides, there are also a small amount of the residual Ti phase and a small oxidation problem due to the open atmosphere. It can be

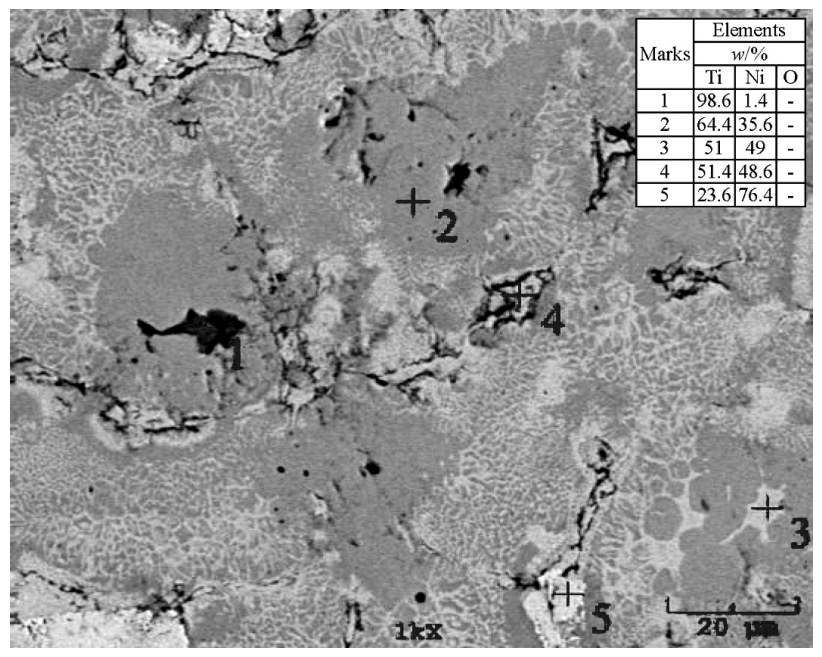

Figure 6: SEM-EDS analyses of NT3 composite

Slika 6: SEM-EDS-analize kompozita NT3

inferred that a high current intensity leads to a high amount of intermetallic phases. According to the ImageJ image-analysis programme, a porosity of $0.2 \%$ can be found in the microstructures.

As can be seen from the SEM and EDS analyses presented in Figure 6, the reaction of the NiTi-compound synthesis was not completed. It is assumed that the applied voltage was insufficient for a complete transformation of the NiTi phases during the sintering.

\subsection{XRD analysis}

The XRD analysis (Figure 7) shows that the main phase of the composite is $\mathrm{NiTi}_{2}$. The NiTi phase is also seen as a small peak. Additionally, $\mathrm{Ni}_{3} \mathrm{Ti}, \mathrm{Ti}$ and $\mathrm{TiO}$ are the other phases existing in the NT3 composite. These results support the observations from the SEM-EDS analysis.

\subsection{Hardness and the elastic modulus}

The measured $\mathrm{HV}_{0.05}$ hardness values for the NT1, NT2 and NT3 samples are $(250 \pm 27),(405 \pm 71)$ and
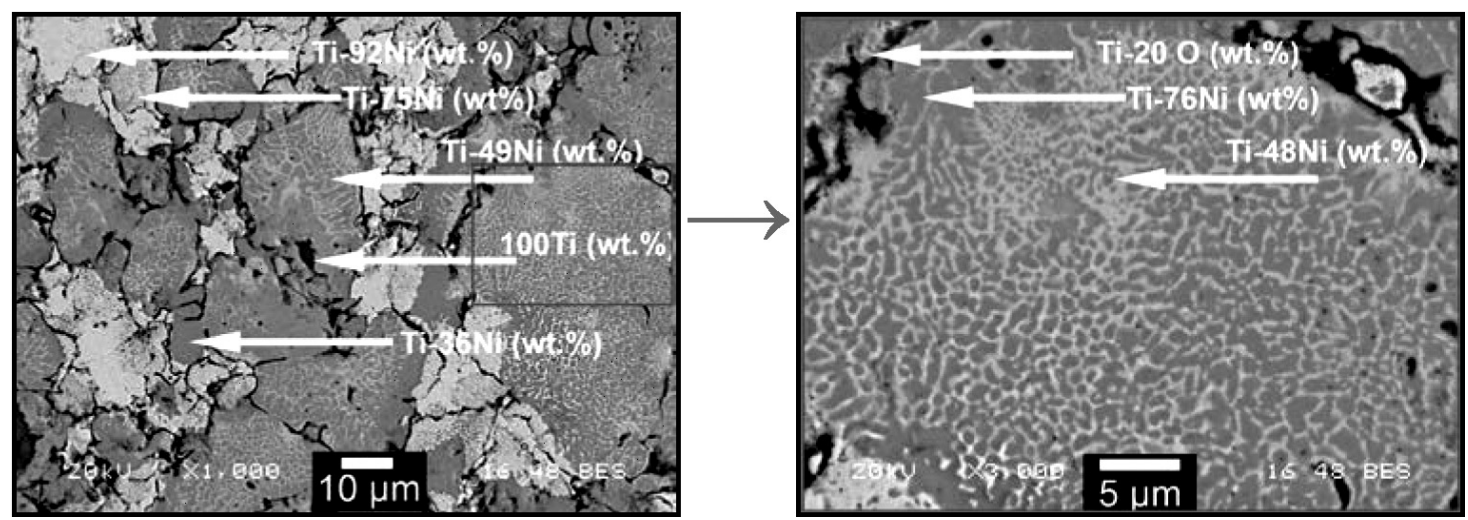

Figure 5: SEM-EDS analyses of NT3 composite

Slika 5: SEM-EDS-analizi kompozita NT3 


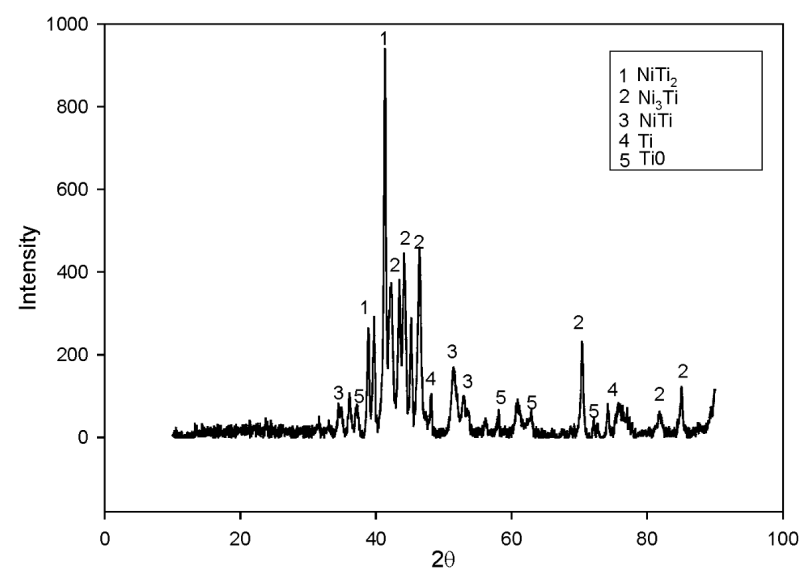

Figure 7: XRD analysis of NT3 sample

Slika 7: Rentgenogram vzorca NT3

$(701.6 \pm 166)$, respectively. The hardness values are in good agreement with the literature. ${ }^{1,12}$ The elastic-modulus values for the NT1, NT2 and NT3 samples determined with the nano-indentation technique are $(98.3 \pm 9)$ $\mathrm{GPa},(120 \pm 23) \mathrm{GPa}$ and $(132 \pm 25) \mathrm{GPa}$, respectively. Nano-indentation is an important technique for probing the mechanical behavior of materials at small-length scales. ${ }^{13}$ The results for the elastic modulus cannot be compared to the literature because of the contrasting reported values. ${ }^{14}$ However, the obtained value of $135 \mathrm{GPa}$ is between the elastic-modulus values for the $\mathrm{Ni}$ and $\mathrm{Ti}$ materials.

\section{CONCLUSIONS}

The reaction of the NiTi-compound synthesis was not completed. It is inferred that the applied voltage was insufficient for a complete transformation of the NiTi phases. When increasing the current intensity from 1000 A to $2000 \mathrm{~A}$, the fractions of intermetallic phases NiTi, $\mathrm{NiTi}_{2}$ and $\mathrm{Ni}_{3} \mathrm{Ti}$ increased as well. There was also a small amount of retained metallic $\mathrm{Ti}$ in the microstructure. The hardness of the intermetallic composites was increased from $250 \mathrm{HV}$ to $701 \mathrm{HV}$ by increasing the current intensity, due to the formation of higher amounts of the intermetallic phases. The elastic modulus of the composites was between the elastic-modulus values for the $\mathrm{Ni}$ and $\mathrm{Ti}$ materials.

\section{Acknowledgements}

This paper was completed within the framework of the PhD work of Mrs. Tuba YENER during a research visit at the TU Dortmund University, the Department of Materials Test Engineering (WPT) between 06-09/2014. The host institution and the home institution, the Sakarya University, the Department of Metallurgy and Materials Engineering, gratefully acknowledge the excellent scientific exchange and the financial support of the $\mathrm{PhD}$ student exchange.

\section{REFERENCES}

${ }^{1} \mathrm{X}$. Songa et al., Microstructure and mechanical properties of $\mathrm{Nb}$ - and Mo-modified NiTi-Al-based intermetallics processed by isothermal forging, Materials Science \& Engineering A, 594 (2014), 229-234, doi:10.1016/j.msea.2013.11.070

${ }^{2}$ N. Ergin et al., An investigation on TiNi intermetallic produced by electric current activated sintering, Acta Physica Polonica A, 123 (2013), 248-249, doi:10.12693/APhysPolA.123.248

${ }^{3} \mathrm{M}$. Farvizi et al., Microstructural characterization of HIP consolidated NiTi-nano $\mathrm{Al}_{2} \mathrm{O}_{3}$ composites, Journal of Alloys and Compounds, 606 (2014), 21-26, doi:10.1016/j.jallcom.2014.03.184

${ }^{4} \mathrm{~F}$. Neves et al., Mechanically activated reactive forging synthesis (MARFOS) of NiTi, Intermetallics, 16 (2008), 889-895, doi:10.1016/j.intermet.2008.04.002

${ }^{5}$ P. Novak et al., Effect of SHS conditions on microstructure of NiTi shape memory alloy, Intermetallics, 42 (2013), 85-91, doi:10.1016/ j.intermet.2013.05.015

${ }^{6} \mathrm{~T}$. Yener et al., Synthesis and characterization of metallic-intermetallic $\mathrm{Ti}^{-\mathrm{TiAl}} \mathrm{l}_{3}, \mathrm{Nb}-\mathrm{Ti}-\mathrm{TiAl}_{3}$ composite produced by electric current activated sintering (ECAS), Mater. Tehnol., 48 (2014) 6, 847-850

${ }^{7} \mathrm{G}$. Chan et al., In-situ observation and neutron diffraction of NiTi powder sintering, Acta Materialia, 67 (2014), 32-44, doi:10.1016/ j.actamat.2013.12.013

${ }^{8}$ Z. Huan et al., Porous NiTi surfaces for biomedical applications, Applied Surface Science, 258 (2012), 5244-5249, doi:10.1016/ j.apsusc.2012.02.002

${ }^{9} \mathrm{M}$. Krasnowski et al., $\mathrm{Al}_{3} \mathrm{Ni}_{2}-\mathrm{Al}$ composites with nanocrystalline intermetallic matrix produced by consolidation of milled powders, Advanced Powder Technology, 25 (2014), 1362-1368, doi:10.1016/ j.apt.2014.03.018

${ }^{10}$ A. Molladavoudi et al., The production of nanocrystalline cobalt titanide intermetallic compound via mechanical alloying, Intermetallics, 29 (2012), 104-109, doi:10.1016/j.intermet.2012.05.012

${ }^{11} \mathrm{R}$. Orrù et al., Consolidation/synthesis of materials by electric current activated/assisted sintering, Materials Science and Engineering R: Reports, 63 (2009), 127-287, doi:10.1016/j.mser.2008.09.003

${ }^{12} \mathrm{~F}$. Gao et al., Abrasive wear property of laser melting/deposited $\mathrm{Ti}_{2} \mathrm{Ni} / \mathrm{TiNi}$ intermetallic alloy, Transactions of Nonferrous Metals Society of China, 17 (2007), 1358-1362, doi:10.1016/S1003-6326 (07)60277-5

${ }^{13} \mathrm{X}$. Deng et al., Deformation behavior of $(\mathrm{Cu}, \mathrm{Ag})-\mathrm{Sn}$ intermetallics by nanoindentation, Acta Materialia, 52 (2004), 4291-4303, doi:10.1016/j.actamat.2004.05.046

${ }^{14}$ Y. Liu et al., Apparent modulus of elasticity of near-equiatomic NiTi, Journal of Alloys and Compounds, 270 (1998), 154-159, doi:10.1016/S0925-8388(98)00500-3 